\title{
Importance of precipitation seasonality for the interpretation of Eemian ice core isotope records from Greenland
}

\author{
W. J. van de Berg ${ }^{1}$, M. R. van den Broeke ${ }^{1}$, E. van Meijgaard ${ }^{2}$, and F. Kaspar ${ }^{3}$ \\ ${ }^{1}$ IMAU, Utrecht University, Utrecht, the Netherlands \\ ${ }^{2}$ KNMI, De Bilt, the Netherlands \\ ${ }^{3}$ Deutscher Wetterdienst - DWD, Offenbach, Germany \\ Correspondence to: W. J. van de Berg (w.j.vandeberg@uu.nl)
}

Received: 17 December 2012 - Published in Clim. Past Discuss.: 17 January 2013

Revised: 5 June 2013 - Accepted: 17 June 2013 - Published: 22 July 2013

\begin{abstract}
The previous interglacial (Eemian, 130$114 \mathrm{kyr}$ BP) had a mean sea level highstand 4 to $7 \mathrm{~m}$ above the current level, and, according to climate proxies, a 2 to $6 \mathrm{~K}$ warmer Arctic summer climate. Greenland ice cores extending back into the Eemian show a reduced depletion in $\delta^{18} \mathrm{O}$ of about $3 \%$ for this period, which suggests a significant warming of several degrees over the Greenland ice sheet. Since the depletion in $\delta^{18} \mathrm{O}$ depends, among other factors, on the condensation temperature of the precipitation, we analyze climatological processes other than mean temperature changes that influence condensation temperature, using output of the regional climate model RACMO2. This model is driven by ERA-40 reanalysis and ECHO-G GCM boundaries for present-day, preindustrial and Eemian climate. The processes that affect the condensation temperature of the precipitation are analyzed using 6-hourly model output. Our results show that changes in precipitation seasonality can cause significant changes of up to $2 \mathrm{~K}$ in the condensation temperature that are unrelated to changes in mean temperature.
\end{abstract}

\section{Introduction}

Isotopes in ice cores provide a high resolution record of past climate. Because water molecules with stable heavy isotopes, i.e. $\mathrm{H}_{2}{ }^{18} \mathrm{O}$ and $\mathrm{HDO}$, favor the liquid and solid phase above the gas phase slightly more than water molecules of their lighter and more abundant species, $\mathrm{H}_{2}{ }^{16} \mathrm{O}$, evaporation causes a depletion of the heavy isotopes, and subsequent condensation reinforces this in the water vapor. For an air parcel traveling poleward and cooling, the relative depletion of stable heavy isotopes is then an indirect measure of latitudinal temperature gradients (Dansgaard, 1964).

Several ice cores drilled in Greenland, for example, GRIP, NorthGRIP and NEEM, provide a record of past climate with annual resolution, extending back into the Eemian, 130 to 114 kyr BP (Johnsen et al., 1992; NorthGRIP community members, 2004; Johnsen and Vinther, 2007; NEEM community members, 2013). Ice cores drilled in Antarctica extend even further back in time, but have a lower temporal resolution due to the lower accumulation rates (Petit et al., 1999; EPICA community members, 2004). In these ice cores, the depletion of stable isotopes like ${ }^{18} \mathrm{O}$ and $\mathrm{D}$ provide a unique measure of past temperatures. However, isotopes provide no direct measure of near-surface air temperature or mean atmospheric temperature. The moisture that is eventually deposited at an ice core site has taken different paths and originates from different latitudes, so no simple relation is expected between temperature and isotopic depletion (e.g. Jouzel et al., 1997; Helsen et al., 2004). After snow deposition, surface snow processes alter the isotopic signal, and diffusion damps the seasonal signal within the snowpack (Johnsen, 1977; Johnsen et al., 2000).

Various Greenland ice cores show lower rates of depletion for the Eemian, suggesting that the Greenland Ice Sheet had a significantly warmer climate during the Eemian than today (Johnsen et al., 1997). For example, Eemian $\delta^{18} \mathrm{O}$ values at NorthGRIP and NEEM are about 3-4\%o higher than present. Using the temperature- $\delta^{18} \mathrm{O}$ relation observed for the present interglacial, this represents an Eemian warming of $8 \pm 4 \mathrm{~K}$ (NEEM community members, 2013). In contrast, 
proxies in the (sub)-Arctic region indicate a 2 to $4 \mathrm{~K}$ summer warming during the Eemian (Kaspar and Cubasch, 2007; Otto-Bliesner et al., 2006). Globally, annual mean land and ocean temperatures were $1.5 \pm 0.1 \mathrm{~K}$ and $0.7 \pm 0.6 \mathrm{~K}$ higher during the Eemian than during the Holocene (Turney and Jones, 2010; McKay et al., 2011, respectively). General Circulation Model (GCM) and Regional Climate Model (RCM) simulations that compare well with Eemian proxy data outside Greenland show only a moderate $1 \mathrm{~K}$ annual warming over Greenland (Kaspar et al., 2005; van de Berg et al., 2011). This discrepancy can be due to model shortcomings, but also partly due to processes that chanced the dependency of isotope depletion on atmospheric temperature, the socalled isotope thermometer. Jouzel et al. (1997) studied the temporal variability of the isotope thermometer, highlighting the effect of changes in evaporative origins of moisture, precipitation seasonality and inversion layer strength. For example, summer precipitation in Greenland generally exceeds winter precipitation (Shuman et al., 2001; Sjolte et al., 2011), introducing a warm bias in the isotope thermometer. During the Last Glacial Maximum, changes in this ratio also significantly affected the isotopic signal (Werner et al., 2000; Sturm et al., 2010). For the Eemian, Masson-Delmotte et al. (2011) showed that precipitation seasonality can have a $1 \%$ effect on annual mean $\delta^{18} \mathrm{O}$.

In this study, impacts of atmospheric circulation and local precipitation processes on current and Eemian isotopic signals in Greenland are analyzed. For this, the condensation temperature $\left(T_{\mathrm{c}}\right)$ of the precipitation is calculated. $T_{\mathrm{c}}$ does not reflect the initial starting temperature of the fractionation process, but the condensation temperature of the precipitation, locally at arrival. $T_{\mathrm{c}}$ captures effects from precipitation seasonality, climatic and atmospheric conditions during precipitation events and the effect of condensation altitude on the isotopic signal. Since isotopic depletion is not simulated in the model, changes in the moisture source location, i.e. effective initial temperature at which fractionation started, are not included. Johnsen et al. (1989) showed that the moisture source for Greenland shifts to lower latitudes for colder climate conditions. The moisture origin has been proven to shift rapidly under glacial conditions (Masson-Delmotte et al., 2005), but also with the phase of the North Atlantic Oscillation (NOA) (Sodemann et al., 2008). Using a fractionation model of intermediate complexity, Sodemann et al. (2008) concluded that for the effect of the NOA on $\delta^{18} \mathrm{O}$, moisture source changes and air temperature changes contribute roughly equally to the variability in $\delta^{18} \mathrm{O}$. Moreover, the cloud arrival temperature, which is comparable with $T_{\mathrm{c}}$ in this study, appears to be a very good proxy of $\delta^{18} \mathrm{O}$, independent of the NAO phase and with a regression slope of about $1 \% \mathrm{~K}^{-1}$ (Sodemann et al., 2008; Fig. 8a). This strong correlation between cloud arrival temperature and $\delta^{18} \mathrm{O}$ does not necessarily exist for moisture source changes between preindustrial conditions and the Eemian. Therefore, Eemian changes in $T_{\mathrm{c}}$ most likely resemble a significant fraction of the change of Eemian $\delta^{18} \mathrm{O}$, but it is not possible to quantify this contribution with certainty.

Section 2 gives a description of the model that has been used for this study and the method to derive $T_{\mathrm{c}}$. Section 3 discusses the processes that cause the differences between $T_{\mathrm{c}}$ and $T_{2 \mathrm{~m}}$ in the present climate. In Sect. 4, we analyze how these processes changed during the Eemian. From these results, conclusions are drawn about the uncertainties that arise if Greenland ice core records are used to estimate local Eemian temperatures.

\section{Data and methods}

\subsection{Model and simulation set-up}

We use present-day, preindustrial and Eemian simulations with the regional atmospheric climate model RACMO, version 2.1 (henceforth RACMO2) of the Royal Netherlands Meteorological Institute (KNMI). RACMO2 is a combination of two numerical weather prediction models: the atmospheric dynamics originate from the High Resolution Limited Area Model (HiRLAM, version 5.0.6; Undén et al., 2002), while the description of the physical processes is adopted from the global model of the European Centre for Medium-Range Weather Forecasts (ECMWF, updated cycle 23r4; White, 2001). Adjustments to the dynamical and physical schemes in RACMO2 are described in detail by van Meijgaard et al. (2008). In addition, for the model version RACMO2, several adjustments have been made to better represent the conditions in the Arctic region, as described in Reijmer et al. (2004) and Ettema et al. (2010b). The model uses a dynamic multilayer snow model that includes all relevant sub-surface processes on an ice sheet, i.e. snow/ice melt, meltwater percolation, (sub-)surface meltwater refreezing, meltwater runoff and snow densification due to compaction and refreezing. Ettema et al. (2009, 2010a,b) showed that RACMO2 accurately simulates the present-day climate of the GrIS. The bias in the mean $2 \mathrm{~m}$ temperature is only $+0.9 \mathrm{~K}(r=0.99)$ and the present-day snow accumulation correlates very well with observations from snow pits and firn cores $(r=0.95)$.

For the present-day simulation, RACMO2 was forced with ECMWF Re-Analysis (ERA-40) boundaries: for the preindustrial and Eemian simulations, weather boundaries from the general circulation model ECHO-G were used. ERA-40 covers the period from September 1957 to mid-2003 (Uppala et al., 2005) at a horizontal resolution of about $1.125^{\circ}$. Data from the period 1960-1989 are used here, since this period ends before the observed recent warming of Greenland, which started around 1990 (van den Broeke et al., 2009). The ECHO-G model (Legutke and Voss, 1999; Legutke and Maier-Reimer, 1999) consists of the ECHAM4 atmosphere model coupled to the HOPE-G ocean model. The atmosphere model has a horizontal resolution of approximately $3.75^{\circ}$ 
Table 1. Climate parameters used in the various runs. The angle of the perihelion is calculated from the vernal equinox. For the simulation of present-day climate, a different routine was used to determine the position of the sun.

\begin{tabular}{lccccccc}
\hline & \multicolumn{3}{c}{ Orbital parameters } & & \multicolumn{2}{c}{ Greenhouse gas concentrations } \\
\cline { 2 - 3 } \cline { 6 - 7 } & Eccentricity & Obliquity $\left[{ }^{\circ}\right]$ & $\begin{array}{c}\text { Angle of } \\
\text { perihelion }\left[{ }^{\circ}\right]\end{array}$ & & $\mathrm{CO}_{2}[\mathrm{ppmv}]$ & $\mathrm{CH}_{4}[\mathrm{ppmv}]$ & $\mathrm{N}_{2} \mathrm{O}[\mathrm{ppbv}]$ \\
\hline $125 \mathrm{kyr}$ BP & 0.0400 & 23.79 & 127.3 & & 270 & 630 & 160 \\
$\begin{array}{l}\text { Preindustrial } \\
\text { Present-day }\end{array}$ & 0.0167 & 23.44 & 282.7 & & 270 & 600 & 270 \\
\hline
\end{tabular}

(T30), and 19 levels in the vertical. The individual simulations comprise several thousand years; Kaspar et al. (2005, 2007) and Kaspar and Cubasch (2007) describe these ECHO$\mathrm{G}$ simulations in detail. The climate simulated by ECHO-G has significant decadal variability; for example, $30 \mathrm{yr}$ averages of of global mean $500 \mathrm{hPa}$ temperature, global mean SST and $500 \mathrm{hPa}$ temperature above Greenland have a range of $0.16,0.16$ and $0.5 \mathrm{~K}$, respectively. To force the RCM simulations, periods with a representative $30 \mathrm{yr}$ mean climate were chosen. Largest deviations of these periods to the integration mean are found for sea surface temperature (SST), but all regional differences of SST remain below $0.4 \mathrm{~K}$.

The coupling of RACMO2 to ERA-40 and ECHO-G is achieved by one-way nesting (van de Berg et al., 2011). At the lateral boundaries, prognostic atmospheric fields force the model every $6 \mathrm{~h}$, while the interior of the domain is allowed to evolve freely. The simulation of the presentday climate was run on a stereographic grid with a resolution of $0.1^{\circ}(11 \mathrm{~km})$; the preindustrial and Eemian simulations were run with a resolution of $0.165^{\circ}(18 \mathrm{~km})$. The $11 \mathrm{~km}$ grid $(\sim 2700 \times 3400 \mathrm{~km})$ extends from the coast of Newfoundland to well beyond Svalbard. The $18 \mathrm{~km}$ grid $(\sim 3700 \times 4700 \mathrm{~km})$ is larger to allow a proper transition from the low-resolution GCM fields. Sea-ice fractions and sea surface temperature were interpolated from the corresponding ERA-40 and ECHO-G grids. The snow/ice pack temperature was initialized using the parameterization of Reeh (1991), including the correction for refreezing. The present-day model integration covers the whole ERA-40 period. Spin-up time is provided by rerunning the first year of ERA-40 three times. For the ECHO-G-driven simulations, the first year is omitted to remove the atmospheric spin-up that occurs in the first days after initialization. In these two simulations, the greenhouse gas concentrations were adapted to the historical rates. For the Eemian simulation, orbital settings at $125 \mathrm{kyr} \mathrm{BP}$ were applied (Table 1). At $125 \mathrm{kyr} \mathrm{BP}$, Northern Hemisphere insolation is close to the maximum for the Eemian, coinciding with the period of maximum temperature on the GrIS (NEEM community members, 2013).

The climate in RACMO2 is largely controlled by the boundary conditions from ECHO-G. Global mean modeled $T_{2 \mathrm{~m}}$ temperatures in ECHO-G are 13.1 and $13.0^{\circ} \mathrm{C}$ for preindustrial and Eemian climate, respectively (Kaspar et al.,
2007). In comparison, the global mean preindustrial and Eemian temperatures were about $0.5^{\circ} \mathrm{C}$ lower (Jansen et al., 2007) and $1.5 \pm 0.1^{\circ} \mathrm{C}$ higher (Turney and Jones, 2010), respectively, than the $1961-1990$ average of $14.0^{\circ} \mathrm{C}$ (Jones et al., 1999). The ECHO-G-driven preindustrial simulation is a few degrees colder over Greenland than the ERA40-driven recent-past simulation, both near the surface as throughout the troposphere. In comparison, global mean SST was $0.7 \pm 0.6^{\circ} \mathrm{C}$ higher during the Eemian compared to the 1961-1990 period (McKay et al., 2011). ECHO-G, however, simulates a $0.1^{\circ} \mathrm{C}$ lower global mean SST during the Eemian compared to the preindustrial climate. We conclude that the preindustrial ECHO-G simulation has a small cold bias: for the Eemian, the model bias of global mean $T_{2 \mathrm{~m}}$ is about 1 to $2{ }^{\circ} \mathrm{C}$. This model bias could be due to vegetation feedbacks or oceanic responses to enhanced ice sheet runoff, two processes that are not included in the ECHO-G model. The Eemian ECHO-G simulation shows no global annual mean warming compared to the preindustrial simulation, but seasonal changes are large. Most importantly, $4{ }^{\circ} \mathrm{C}$ higher summer temperatures are simulated for the Northern Hemisphere land area, i.e. north of $30^{\circ} \mathrm{N}$. As a result, the amplitude of the seasonal temperature cycle in this region increased by $4.6^{\circ} \mathrm{C}$. This Northern Hemispheric summer warming is also observed, for example, in summer lake temperatures on Baffin Island, Arctic Canada, which were 5 to $10 \mathrm{~K}$ higher during the Eemian than now (Francis et al., 2006). RACMO2 simulates 3-4 K higher July temperatures for eastern Baffin Island compared to the preindustrial climate. Francis et al. (2006) noted that summer lake temperatures exceed air temperatures due to the direct heating of the lake water by sunlight.

\subsection{Derivation of the condensation temperature}

Since RACMO2 does not explicitly calculate stable water isotopes, the condensation temperature $T_{\mathrm{c}}$ is used as a proxy for $\delta^{18} \mathrm{O} . T_{\mathrm{c}}$ is the weighted mean temperature of the model levels at which the precipitation is formed. In a model time step of 10 to $15 \mathrm{~min}$, most of the cloud liquid and ice water content (CWC) that is formed rains out directly. Advection of $\mathrm{CWC}$ is a minor contribution to the local precipitation flux $(<10 \%)$. It is thus assumed that the vertical gradient of the precipitation flux is a good measure of the local total 
condensation. Moreover, CWC is advected along the same trajectory as temperature. Therefore, temperature differences along the cloud content trajectory will be small.

In order to calculate the condensation temperature, daily profiles of precipitation fluxes, 6 hourly temperature profiles and 6 hourly surface precipitation fluxes were used. For each $6 \mathrm{~h}$, the condensation temperature of the precipitation was determined, using the mean temperature for this $6 \mathrm{~h}$ and the daily profile of the precipitation flux.

The condensation temperature $T_{\mathrm{c}}$ at time $t$ is defined as

$\left(T_{\mathrm{c}}\right)_{t}=\frac{\int_{0}^{\infty} T_{t z} C_{t z} \mathrm{~d} z}{\int_{0}^{\infty} C_{t z} \mathrm{~d} z}=\frac{1}{P_{t}} \int_{0}^{\infty} T_{t z} C_{t z} \mathrm{~d} z$

in which $C_{t z}$ and $T_{t z}$ are the net precipitation formation and the temperature at level $z$ and time $t$, respectively. The integrated precipitation formation, $\int_{0}^{\infty} C_{t z} \mathrm{~d} z$, equals the net precipitation $P_{t}$. Precipitation that evaporates during descent is not counted, therefore $C_{t z}$ represents the condensate that reaches the surface. By integrating $\left(T_{\mathrm{c}}\right)_{t}$ over several decades, thus

$$
T_{\mathrm{c}}=\frac{\int_{0}^{T} \int_{0}^{\infty} T_{t z} C_{t z} \mathrm{~d} z \mathrm{~d} t}{\int_{0}^{T} P_{t} \mathrm{~d} t}=\frac{1}{P} \int_{0}^{T} \int_{0}^{\infty} T_{t z} C_{t z} \mathrm{~d} z \mathrm{~d} t,
$$

the effects of seasonal and interannual variability are included.

The time-average precipitation profile temperature $\left(T_{\mathrm{pp}}\right)$ is the mean temperature $\left(T_{z}\right)$ convoluted with the vertical condensation profile,

$T_{\mathrm{pp}}=\frac{1}{P} \int_{0}^{\infty} T_{z} \int_{0}^{T} C_{t z} \mathrm{~d} t \mathrm{~d} z$.

This temperature $T_{\mathrm{pp}}$ is the weighted average over the elevations at which precipitation has formed.

The difference between $T_{2 \mathrm{~m}}$ and $T_{\mathrm{pp}}$ reflects the difference between the temperature near the surface and the part of the atmosphere that is relevant for precipitation formation. Differences between $T_{\mathrm{c}}$ and $T_{\mathrm{pp}}$ are due to the temporal variability of precipitation and condensation and originate from two sources. Firstly, the atmospheric temperature during precipitation events deviates from the mean temperature for that time of the year $\left(d T_{\text {event }}\right)$. Secondly, the precipitation events are unequally distributed over the year $\left(d T_{\text {seas }}\right)$. To calculate $d T_{\text {event }}$, the difference between $T_{\mathrm{pp}}$ and $T_{\mathrm{c}}$ is derived for each individual month, and this difference is the weighted averaged over the whole period, thus

$d T_{\text {event }}=\frac{1}{P} \sum\left(T_{\mathrm{c}}-T_{\mathrm{pp}}\right)_{\mathrm{month}} \cdot P_{\mathrm{month}}$.
A weighted average is used for $d T_{\text {event }}$, because $T_{\mathrm{c}}$ can be unrepresentative in months with very little precipitation. Using a normal average for $d T_{\text {event }}$ would, therefore, lead to erroneous estimates of $d T_{\text {event }}$ and subsequently $d T_{\text {seas. }}$. However, using a weighted average causes $d T_{\text {event }}$ to be affected by the precipitation seasonality, since $d T_{\text {event }}$ is generally larger during winter than during summer. As will be shown later, this has little impact on the results.

The effect of precipitation seasonality causes the remaining difference between $T_{\mathrm{pp}}$ and $T_{\mathrm{c}}$ :

$d T_{\text {seas }}=T_{\mathrm{c}}-T_{\mathrm{pp}}-d T_{\mathrm{event}}=\left(\frac{1}{P} \sum T_{\mathrm{pp}, \text { month }} \cdot P_{\text {month }}\right)-T_{\mathrm{pp}}$.

Differences between $T_{\mathrm{pp} \text {, month }}$ and $T_{\mathrm{pp}}$ are caused by variability of the atmospheric temperature and condensation altitude (Eq. 2). A month with a lower mean condensation altitude or higher atmospheric temperature than average causes a higher $T_{\mathrm{pp} \text {,month }}$ than $T_{\mathrm{pp}}$. For example, summer months have a higher $T_{\mathrm{pp}}$, month than the climatological average $T_{\mathrm{pp}}$. These monthly deviations of $T_{\mathrm{pp} \text {, month }}$ turn into a nonzero $d T_{\text {seas }}$ if $P_{\text {month }}$ has a seasonal signal. For example, if a location receives precipitation predominantly during the summer season, $d T_{\text {seas }}$ is positive. Similarly to $d T_{\text {seas }}$, the effect of interannual variability on $T_{\mathrm{c}}$ can be determined if Eq. (4) is evaluated over yearly time intervals.

Analogous to $T_{\mathrm{c}}$ (Eq. 1), a mean $2 \mathrm{~m}$ temperature can be derived for precipitation events $\left(T_{2 \mathrm{~m}, \mathrm{p}}\right)$ with

$T_{2 \mathrm{~m}, \mathrm{p}}=\frac{1}{P} \int_{0}^{T} T_{2 \mathrm{~m}, \mathrm{t}} P_{t} \mathrm{~d} t$,

in which $T_{2 \mathrm{~m}, \mathrm{t}}$ is the $2 \mathrm{~m}$ temperature at time $t$. The difference between $T_{2 \mathrm{~m}, \mathrm{p}}$ and the mean $T_{2 \mathrm{~m}}$ is solely due to temporal precipitation variability. The effects of seasonality and short-term variability on $T_{2 \mathrm{~m}, \mathrm{p}}$ can be isolated similarly as in Eq. (3).

\subsection{Discussion of example profiles}

Figure 1a shows three example profiles of mean temperature (solid) and mean condensation temperature (dashed), of which two are inland profiles and one is marine. The two inland temperature profiles, starting at $2.8 \mathrm{~km}$ (South Dome) and $3 \mathrm{~km}$ (NorthGRIP) height, show the well known surface inversion layer, which is stronger at NorthGRIP than at South Dome. At these two locations, the mean condensation temperature is higher than the mean temperature for the whole column. Hence, precipitation occurs during warmer than average conditions, or during the warmer part of the year. At the ocean point $\left(65^{\circ} \mathrm{N}, 30^{\circ} \mathrm{W}\right)$, no stable boundary layer is formed due to the presence of warm ocean water. Furthermore, in a $1 \mathrm{~km}$-deep layer centered at around $2 \mathrm{~km}$ elevation, a significant contribution of convective precipitation (Fig. 1b) lowers the condensation temperature below the mean temperature. Convection is forced by large vertical temperature 

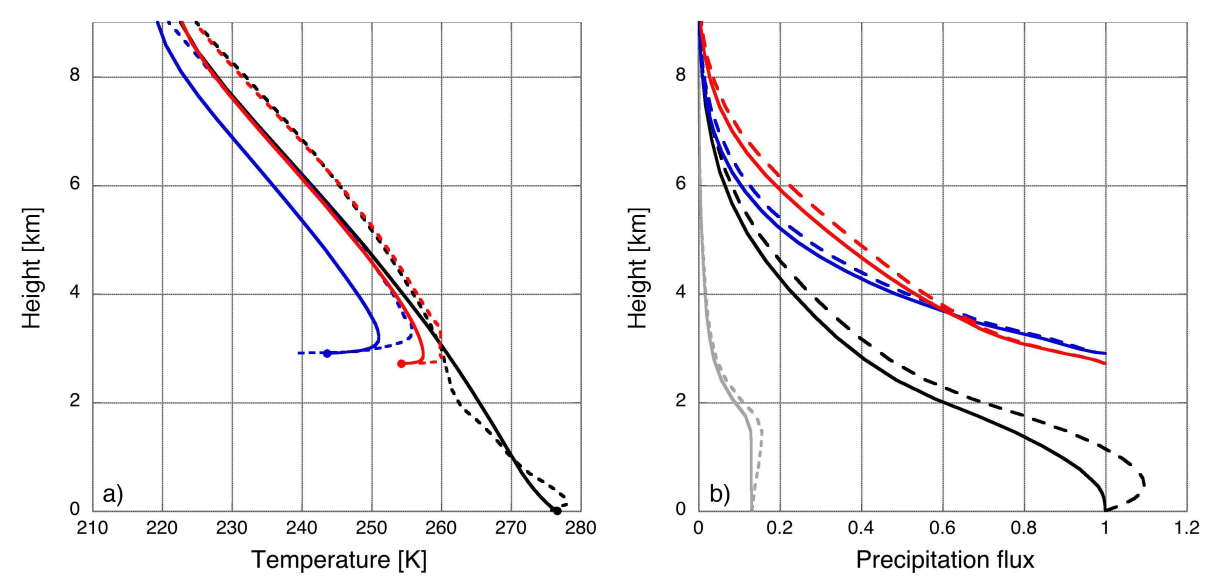

Fig. 1. (a) Average temperature profile (solid), $2 \mathrm{~m}$ temperature (line end dots) and mean temperature profile for precipitation events (dashed). (b) Vertical profile of precipitation flux. Net and total precipitation fluxes are drawn with a solid and dashed line, respectively. The profiles of NorthGRIP $\left(75.1^{\circ} \mathrm{N}, 43.32^{\circ} \mathrm{W}\right)$, South Dome $\left(62.5^{\circ} \mathrm{N}, 45^{\circ} \mathrm{W}\right)$ and a point over sea $\left(65^{\circ} \mathrm{N}, 30^{\circ} \mathrm{W}\right)$ are shown in blue, red and black, respectively. The grey lines are the net and total convective precipitation for the point over sea. All values are scaled with the net precipitation.

gradients. With a sea surface temperature that is almost constant year round, convective precipitation then falls during periods where the atmosphere is colder than average. Due to the generally warmer conditions over sea, evaporation of precipitation also is a more important process: the precipitation flux at $500 \mathrm{~m}$ is $10 \%$ larger than the amount of precipitation that reaches the surface. Over the Greenland ice sheet, convective precipitation as well as evaporation of precipitation are both of limited importance: all precipitation is formed by large-scale dynamic or topographic lifting.

Although the two inland examples appear rather similar, at NorthGRIP the precipitation is formed closer to the surface than at South Dome. The mean condensation elevation at South Dome and NorthGRIP is 4.54 and $4.29 \mathrm{~km}$ elevation, respectively. The atmosphere above NorthGRIP is colder than above South Dome, so this lower precipitation origin reduces the difference of $T_{\mathrm{c}}$ between both sites (249.7 and $252.6 \mathrm{~K}$, respectively). The difference in $T_{2 \mathrm{~m}}$ between these two sites is $10.7 \mathrm{~K}$.

\section{Contemporary climate}

\subsection{Mean condensation temperature}

The spatial patterns of $T_{2 \mathrm{~m}}, 500 \mathrm{hPa}$ temperature $\left(T_{500 \mathrm{hPa}}\right)$ and $T_{\mathrm{c}}$, averaged for 1960-1989, are presented in Fig. 2. Figure 2a shows mean $T_{2 \mathrm{~m}}$ as simulated by RACMO2, with well-known features such as a north-south temperature gradient over the ocean, where the $271 \mathrm{~K}$ isotherm demarcates the winter extent of the sea ice. Over Greenland, isotherms follow the elevation contour lines combined with a northsouth gradient. Longitudinal gradients are also visible, southeast Greenland being warmer than south-west Greenland, and north-west Greenland being warmer than north-east Greenland.

Compared to $T_{2 \mathrm{~m}}$, mean $T_{\mathrm{c}}$ (Fig. 2b) is much less variable. Gradients over the ocean are largely reduced, becoming even smaller than the gradient in $T_{500 \mathrm{hPa}}$. The difference between $T_{\mathrm{c}}$ and $T_{2 \mathrm{~m}}$ exceeds $20 \mathrm{~K}$ over warm ocean water, but goes to zero over the ice-covered Arctic ocean. The mean condensation altitude decreases towards higher latitudes, counterbalancing the effect of lower air temperatures (not shown). More pronounced gradients in $T_{\mathrm{c}}$ are found over Greenland, where topography is the primary factor determining the mean condensation temperature; latitude is of less importance.

\subsection{Factors determining the condensation temperature}

Two factors determine the difference between $T_{2 \mathrm{~m}}$ and $T_{\mathrm{c}}$ (Fig. 2), namely, spatial and temporal temperature differences. Figure $3 \mathrm{a}$ shows the difference between the mean temperature of the air in which the condensation occurs $\left(T_{\mathrm{pp}}\right)$ and $T_{2 \mathrm{~m}}$. As visible in Fig. 1b, condensation is unevenly distributed in the troposphere, which is included in the calculation of $T_{\mathrm{pp}}$ (see Eq. 2).

Vertical temperature differences explain most of the difference between $T_{\mathrm{c}}$ and $T_{2 \mathrm{~m}}$ (Fig. 2), especially for warmer locations such as over the Atlantic Ocean. Over the ocean, the mean condensation altitude decreases with latitude due to the colder atmospheric conditions, largely balancing the latitudinal temperature gradient. South of Iceland, the mean condensation altitude is about $2.9 \mathrm{~km}$, near Spitsbergen it is about $1.9 \mathrm{~km}$. Note that $T_{\mathrm{pp}}$ is not always lower than $T_{2 \mathrm{~m}}$. The mean condensation elevation increases less with topography than the topography itself. As a result, condensation occurs relatively close to the surface over the high elevation areas of the ice sheet. In combination with the strong surface-based temperature inversion, which is common for the northern 


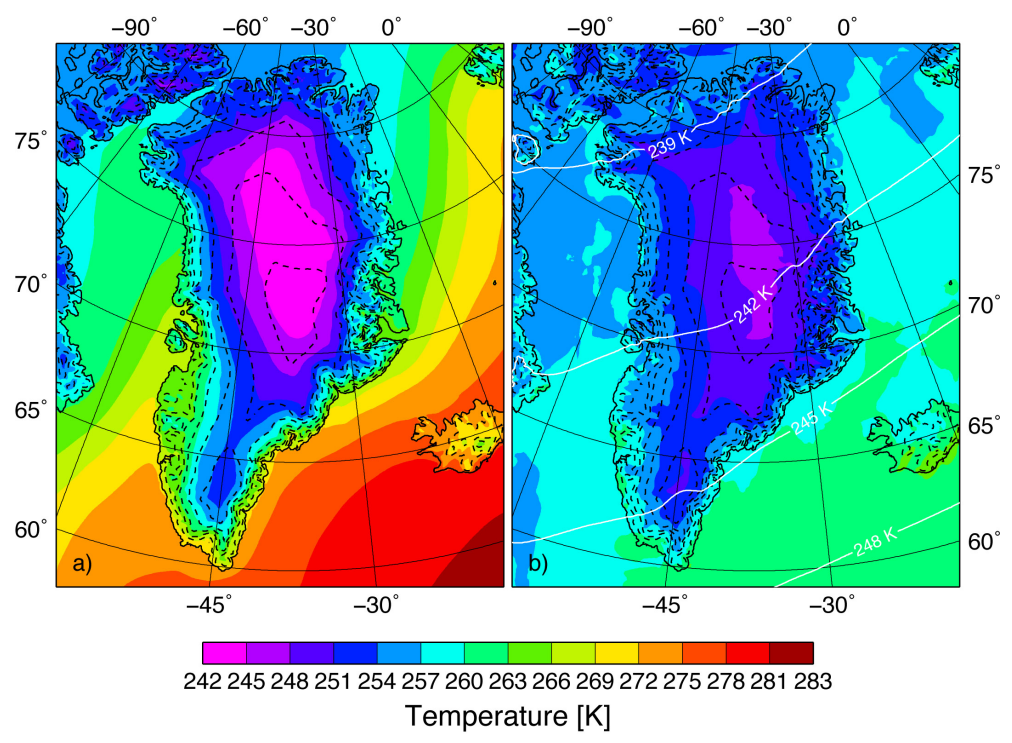

Fig. 2. Mean modeled 1960-1989 averages of (a) $T_{2 \mathrm{~m}}$, (b) $T_{\mathrm{c}}$ and $T_{500 \mathrm{hPa}}$ (white lines).


Fig. 3. Differences between $T_{\mathrm{c}}$ and $T_{2 \mathrm{~m}}$ for the current climate due to (a) differences between $T_{\mathrm{pp}}$ and $T_{2 \mathrm{~m}}$; (b) temperature differences between "wet" and mean conditions $\left(d T_{\text {event }}\right)$; (c) precipitation seasonality and interannual variability $\left(d T_{\text {seas }}\right)$.

GrIS, this causes $T_{\mathrm{pp}}$ to be equal to or even slightly higher than $T_{2 \mathrm{~m}}$.

The remainder of the difference between $T_{\mathrm{c}}$ and $T_{2 \mathrm{~m}}$ is determined by temporal variability, and the maximum impact is about $5 \mathrm{~K}$. The effect of temporal variability is either due to short-term variability $\left(d T_{\text {event }}\right.$, Fig. $\left.3 \mathrm{~b}\right)$ or due to precipitation seasonality ( $d T_{\text {seas }}$, Fig. 3c). A positive $d T_{\text {event }}$ (Fig. 3b) implies that days with precipitation have higher atmospheric temperatures than average for that specific time of the year. $T_{2 \mathrm{~m}}$ is in general higher on days with precipitation, because precipitation coincides not only commonly with warm-air advection, but also with cloudy conditions and usually with enhanced winds, which both reduce the strength of the near-surface temperature inversion. This effect on the mean $T_{2 \mathrm{~m}}$ during precipitation can be up to $8 \mathrm{~K}$ (not shown). However, the spatial patterns in atmospheric $d T_{\text {event }}$ are different from those for $T_{2 \mathrm{~m}}$ and $d T_{\text {event }}$. Moreover, little condensation occurs in the shallow atmospheric boundary layer; $d T_{\text {event }}$ is mainly caused by other processes. $d T_{\text {event }}$ becomes significant if precipitation events are associated with certain large-scale flow patterns. For most of Greenland, precipitation occurs when warm, moist air from the south flows over the ice sheet. The exception to this pattern is north Greenland, where $d T_{\text {event }}$ is negative. This part of Greenland is on the lee side of the ice cap for warm air moving northward. Warm, northward-moving air is thus descending here, and 


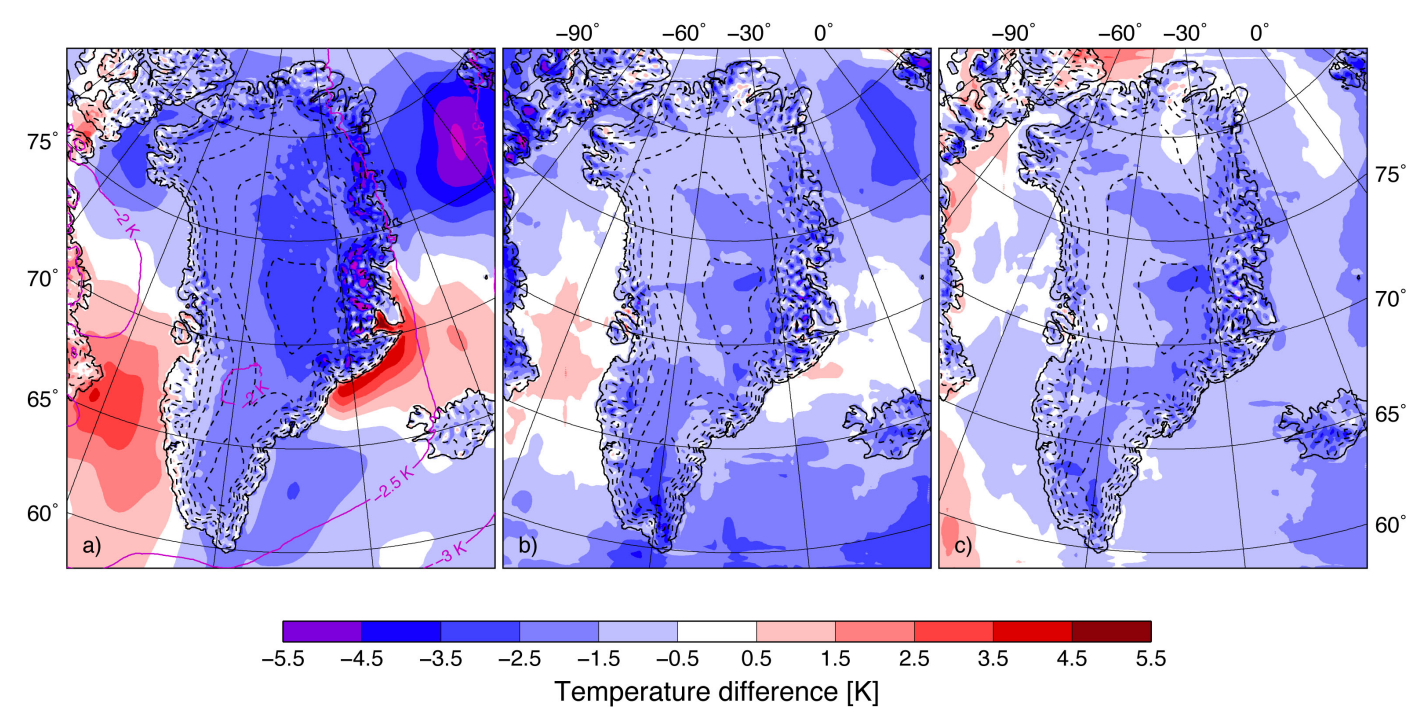

Fig. 4. Differences between the simulated preindustrial and 1960-1989 climate. Change in (a) $T_{2 \mathrm{~m}}, T_{500 \mathrm{hPa}}$ (purple contours), (b) $T_{\mathrm{pp}}$ and (c) $T_{\mathrm{c}}$. Negative values imply that the preindustrial simulation is colder than the 1960-1989 simulation.

therefore too dry to generate precipitation. Precipitation has to come from the Arctic Ocean, which results in colder atmospheric conditions during precipitation events.

Over most of Greenland and the sea-ice-covered ocean, seasonality has a warming impact on $T_{\mathrm{c}}$ (Fig. 3c). Summer precipitation exceeds winter precipitation, and the effect of seasonality is strongest for dry and cold locations. The effect of interannual variability on $d T_{\text {seas }}$ is negligible. Besides the temperature-moisture effect - cold air carries less moisture, and produces less precipitation - sea ice is an important factor. Sea ice shields the sea from an effective exchange of moisture and energy with the atmosphere. It also allows the build-up of a surface inversion, which stabilizes the atmosphere and prevents vertical mixing. As a result, the winter months are dryer than the summer period over the sea ice. Over the northern Atlantic Ocean, seasonality has a cooling effect on $T_{\mathrm{c}}$. Here, most of the precipitation is due to cyclonic activity, which is significantly stronger during the winter period than in summer. Since south-east Greenland receives most of is precipitation by cyclones that develop at the southern tip of Greenland and travel to the north-east, $d T_{\text {seas }}$ is negative in this coastal region, too.

\section{Eemian changes}

In the previous section, the processes that influence the condensation temperature in the present climate have been discussed. In this section it will be shown how these processes might have been different during the Eemian by comparing results of the ECHO-G model for Eemian and preindustrial conditions. For a description of the ECHO-G model setup and simulations, see Sect. 2.1. For a consistent analysis of Eemian anomalies, the Eemian RACMO2 simulation is compared with a preindustrial RACMO2 control run, both with boundary conditions from the ECHO-G model. First, the preindustrial control run is compared with the ERA-40driven run analyzed in the previous sections. As shown in Fig. 4, the preindustrial simulation is colder than the recentpast simulation (Fig. 4a), leading to a lower $T_{\mathrm{pp}}$ (Fig. 4b) and $T_{\mathrm{c}}$ (Fig. 4c). The preindustrial climate in the Northern Hemisphere was by about $0.3 \mathrm{~K}$ colder than the recent-past climate (Jansen et al., 2007). This was partly due to the absence of anthropogenic climate warming, but this figure shows that ECHO-G also likely has a cold bias over Greenland. In the preindustrial climate realization, $T_{2 \mathrm{~m}}$ decreased more than $T_{\mathrm{pp}}$ in Greenland. The contributions of $d T_{\text {event }}$ and $d T_{\text {seas }}$ to preindustrial $T_{\mathrm{c}}$, however, remain similar to the recent-past contribution, hence preindustrial anomalies in $T_{\mathrm{c}}$ (Fig. 4c) are very comparable to the anomalies in $T_{\mathrm{pp}}$ (Fig. 4b). We conclude that, despite the differences and the likely cold bias, the ECHO-G-driven simulation provides a realistic realization of the preindustrial precipitation climate of Greenland.

Figure 5 shows the changes in $T_{2 \mathrm{~m}}, T_{500 \mathrm{hPa}}, T_{\mathrm{c}}$ and the difference between $T_{2 \mathrm{~m}}$ and $T_{\mathrm{c}}$ during the Eemian compared to the preindustrial climate. A modest near-surface warming of up to $1 \mathrm{~K}$ is simulated for Greenland (Fig. 5a). For large areas along the southern coastal margins, this warming is not significant. This significance $(2 \sigma)$ is derived using the interannual variability in the temperature; other processes causing uncertainty, for example, decadal variability or uncertainties in the GCM climate, can not be easily quantified. The simulated annual mean warming is the result of strong summer warming, up to $3 \mathrm{~K}$, and winter and spring cooling. A similar annual mean warming and increased amplitude of the seasonal temperature cycle is found in the free atmosphere. For example, the annual mean $T_{500 \mathrm{hPa}}$ rises by 


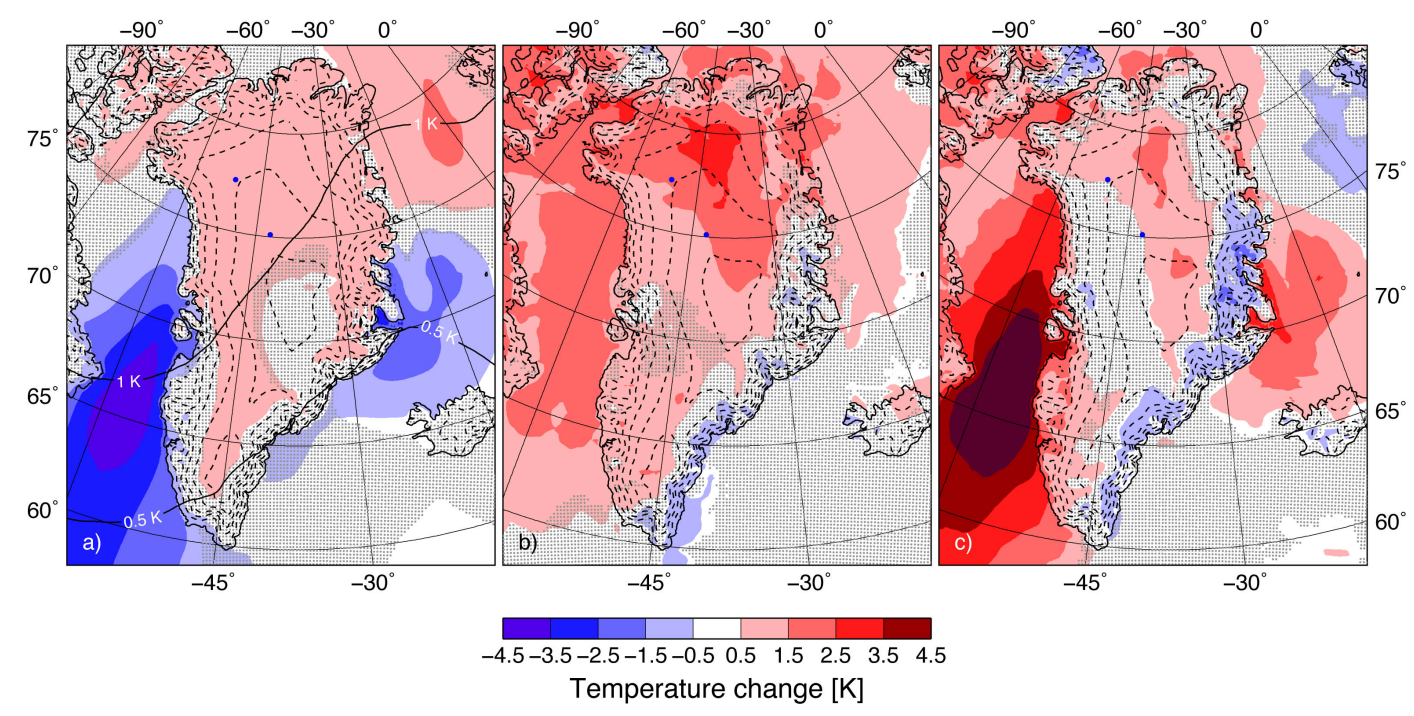

Fig. 5. Changes in the Eemian with respect to the preindustrial simulation for (a) $T_{2 \mathrm{~m}}, T_{500 \mathrm{hPa}}$ (contours), (b) $T_{\mathrm{c}}$ and (c) the difference between $T_{\mathrm{c}}$ and $T_{2 \mathrm{~m}}$. Areas with differences that fail to reach significance at $2 \sigma$ level are dotted (blue dots represent the locations of NorthGRIP and NEEM).

0.3 to $1.2 \mathrm{~K}$ over Greenland (Fig. $5 \mathrm{a}$ ), while summer $T_{500 \mathrm{hPa}}$ rises by 2 to $4 \mathrm{~K}$. The enhanced seasonal temperature cycle is caused by the enhanced summer insolation and decreased insolation during the Northern Hemisphere winter. Although the ocean surface has a lower albedo than land, land has a limited effective heat capacity, allowing the land surface temperature to respond faster to enhanced insolation. Eemian Northern Hemisphere winter and spring temperatures are below preindustrial values; during the Eemian Northern Hemisphere winter, the earth passes through the aphelion. In the current orbit, the Earth passes through perihelion during the Northern Hemisphere winter. The RACMO2 and ECHO-G simulations display no global annual mean warming, in contrast to Eemian with a positive anomaly of about $1 \mathrm{~K}$ from proxy data (Turney and Jones, 2010; McKay et al., 2011), but clearly, the Northern Hemisphere summer anomaly is much larger than the annual mean anomaly. Moreover, little correspondence exists between the $T_{2 \mathrm{~m}}$ temperature change and that in the free atmosphere, a result of different mechanisms driving free atmosphere and near-surface warming. Especially over the ocean the differences are distinct. $T_{2 \mathrm{~m}}$ over the ocean is controlled by the water temperature, and its changes reflect changes in ocean circulation and ice cover. A warming of Fram Strait area is simulated, due to reduced sea ice cover, and a cooling in the Labrador Sea, due to a reduced entrainment of warm Atlantic water. Both patterns are persistent through the whole Eemian simulations.

The change in condensation temperature $T_{\mathrm{c}}$ in Fig. $5 \mathrm{~b}$ is on average larger than that in $T_{2 \mathrm{~m}}$ and $T_{500 \mathrm{hPa}}$ and ranges from -1 to $+3 \mathrm{~K}$. Whereas insignificant changes are found over the Atlantic Ocean, higher $T_{\mathrm{c}}$ values are found over most of Greenland and its surrounding seas with seasonal sea ice cover, with a maximum increase over North Greenland. Again, little spatial correspondence exists between changes in $T_{\mathrm{c}}$ and either $T_{2 \mathrm{~m}}$ and $T_{500 \mathrm{hPa}}$. For large parts of the GrIS, the change in $T_{\mathrm{c}}$ is not significantly different from the change in $T_{2 \mathrm{~m}}$ (Fig. 5c). Only for north and central Greenland, $T_{\mathrm{c}}$ increased more than $T_{2 \mathrm{~m}}$, including the areas around the GRIP, NorthGRIP and NEEM drill sites. In contrast, the $T_{\mathrm{c}}$ increase is significantly smaller than the $T_{2 \mathrm{~m}}$ increase for part of the eastern coast of Greenland, including the Renland ice cap. The change difference between $T_{\mathrm{c}}$ and $T_{500 \mathrm{hPa}}$ over Greenland (not shown) is comparable to Fig. 5c. For the northfacing northern part of GrIS, a significantly larger increase of $T_{\mathrm{c}}$ than $T_{500 \mathrm{hPa}}$ is found and a significantly smaller and even negative change is found along the southeastern coast.

\section{Factors determining Eemian changes}

In Sect. 3.2, the difference between $T_{\mathrm{c}}$ and $T_{2 \mathrm{~m}}$ was attributed to differences in $T_{2 \mathrm{~m}}$ and $T_{\mathrm{pp}}, d T_{\text {event }}$ and $d T_{\text {seas. }}$. Figure 6 shows how these contributions differ between the Eemian and preindustrial climate. Changes in the difference between $T_{\mathrm{pp}}$ and $T_{2 \mathrm{~m}}$ (Fig. 6a) are significant, especially over the ocean, indicating that the ocean surface cooling did not result in a similar decrease of $T_{\mathrm{pp}}$. Over Greenland, the change is slightly negative, with the largest changes in areas with enhanced refreezing. Snow melt and subsequent refreezing is an effective way to bring energy into the snow pack. This energy is released into the atmosphere during the winter season, causing the positive anomaly of $T_{2 \mathrm{~m}}$ over Greenland (Fig. 5a). Over land, the changes in the difference between $T_{500 \mathrm{hPa}}$ and $T_{\mathrm{pp}}$ (not shown) are comparable to those between $T_{2 \mathrm{~m}}$ and $T_{\mathrm{pp}}$, shown in Fig. 6a. Over sea, $T_{\mathrm{pp}}$ became lower than $T_{500 \mathrm{hPa}}$ by up to $3 \mathrm{~K}$; the spatial patterns relate 


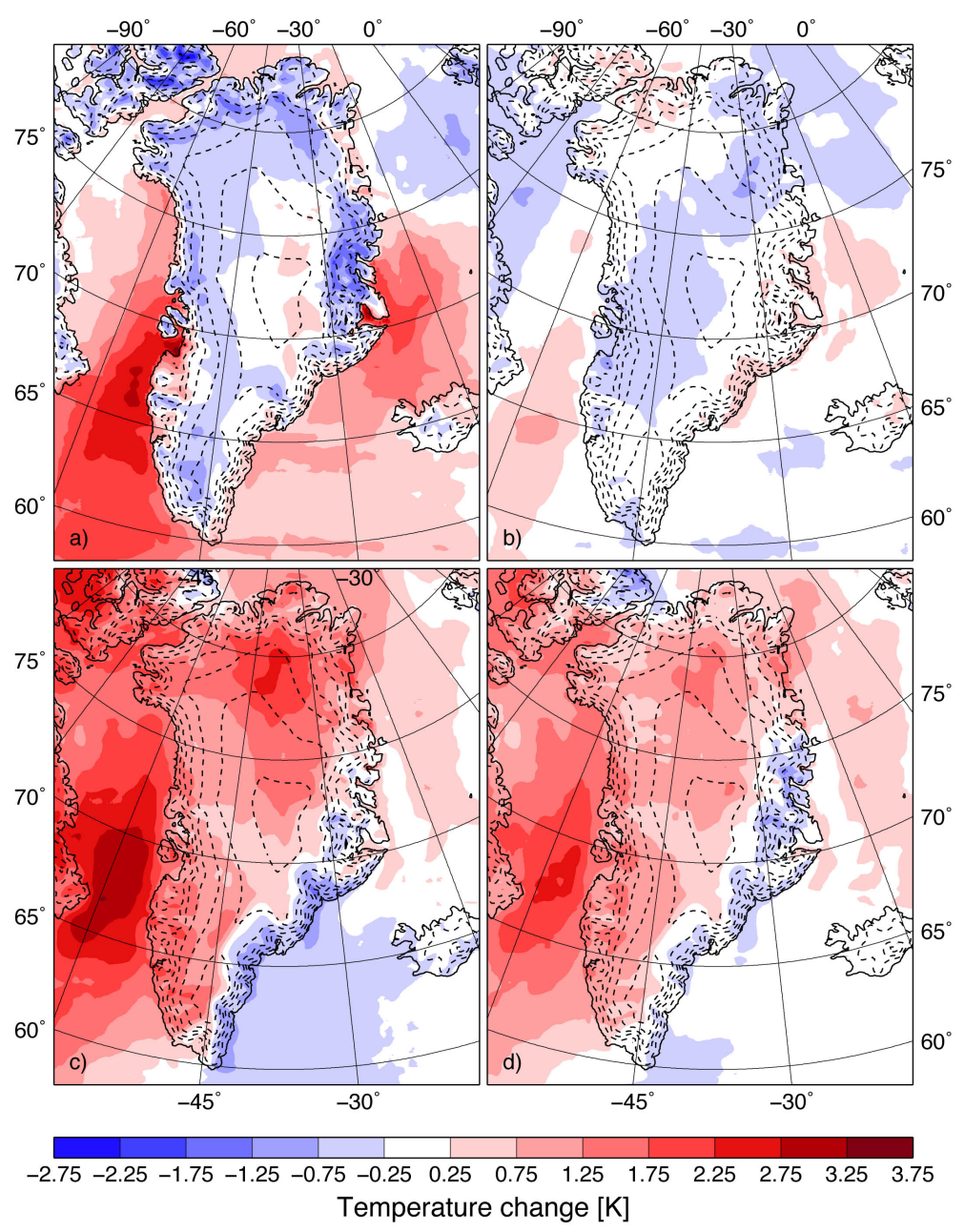

Fig. 6. Components of the changes in $T_{2 \mathrm{~m}}$ and $T_{\mathrm{c}}$. (a) Change in difference between $T_{\mathrm{pp}}$ and $T_{2 \mathrm{~m}}$; (b) change in $d T_{\text {event }}$; (c) change in $d T_{\text {seas }} ;(\mathbf{d})$ change in $T_{\mathrm{c}}$ due to enhanced precipitation seasonality only.

closely to the spatial patterns of Eemian ocean surface cooling (Fig. 5a). The changes in the temperature difference between precipitation events and average conditions ( $d T_{\text {event }}$, Fig. 6b) are relatively minor.

The main reason for Eemian $T_{\mathrm{c}}$ to rise more than $T_{2 \mathrm{~m}}$ is precipitation seasonality ( $d T_{\text {seas }}$, Fig. 6c). For most of Greenland, precipitation events in the present climate are biased to the warmer part of the year (Fig. 3c), and this bias is enhanced in the Eemian. The spatial patterns in Figs. 3c and 6c are therefore comparable. Remarkably, the modeled cooling of the Labrador Sea coincides with a strong increase of the regional precipitation seasonality.

The changes in precipitation seasonality has two components: a temperature and a precipitation contribution. Enhanced Eemian temperature seasonality can alter $T_{\mathrm{c}}$ in places where the precipitation is already unevenly distributed over the year. This enhances $T_{\mathrm{c}}$ by up to $1 \mathrm{~K}$ in northern Greenland, Ellesmere Island and the Labrador Sea and decreases it along the southeastern coast of Greenland (not shown). This pattern is different from the present-day seasonality effect (Fig. 3c). This is because most Eemian warming occurs during late summer and early fall (July to October), lagging the insolation anomaly, which peaks in June. Winter and early spring (December to May) were on average colder in the Eemian. Hence, a positive effect of precipitation seasonality on $T_{\mathrm{c}}$ for preindustrial conditions does not necessarily cause a similar effect for the Eemian. Nevertheless, its largest contribution is in areas with the largest present-day seasonality effect. The second component, changes in the precipitation seasonality, is the main contribution to changes in $d T_{\text {seas }}$. The effect of the enhanced precipitation seasonality on $T_{\mathrm{c}}$ is shown in Fig. $6 \mathrm{~d}$ and causes an increase of $T_{\mathrm{c}}$ of up to $1.5 \mathrm{~K}$ in northern Greenland. Maximum contribution is not only modeled for Northern Greenland, but also along the west coast. Concluding, the change in $T_{\mathrm{c}}$ has the largest positive anomalies compared to the change in $T_{2 \mathrm{~m}}$ in regions for which in the present-day climate precipitation is mostly received in the summer months and experienced a significant summer 

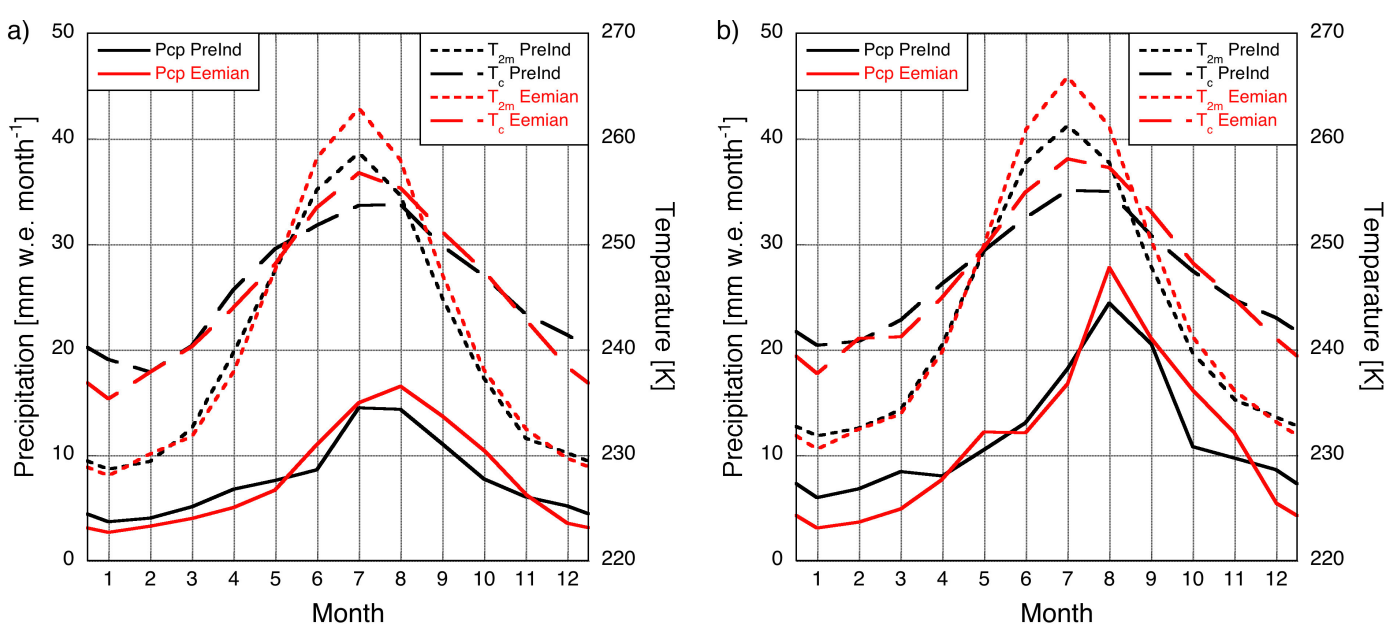

Fig. 7. Annual cycle of precipitation, $T_{2} \mathrm{~m}$ and $T_{\mathrm{c}}$ for Preindustrial and Eemian conditions at (a) NorthGRIP $\left(75.1^{\circ} \mathrm{N}, 42.32^{\circ} \mathrm{W}\right)$ and (b) $\operatorname{NEEM}\left(77.45^{\circ} \mathrm{N}, 51.06^{\circ} \mathrm{W}\right)$.

warming and precipitation seasonality enhancement during the Eemian. Of these three factors, the Eemian precipitation seasonality change is least certain. Nevertheless, these model results show that stable isotope data from Northern Greenland ice cores are susceptible to be biased by changes in precipitation seasonality.

The role of precipitation seasonality is further visualized in Fig. 7. For two deep ice core drilling sites, NorthGRIP and NEEM, the mean monthly values of precipitation, $T_{2 \mathrm{~m}}$ and $T_{\mathrm{c}}$ are shown for the preindustrial and Eemian simulations. For both sites, a significant Eemian summer warming is simulated, which is most pronounced in $T_{2 \mathrm{~m}}$. A significant cooling of $T_{\mathrm{c}}$ is visible for the Eemian winter, while $T_{2 \mathrm{~m}}$ remains almost unchanged. If precipitation variability is neglected, $T_{2 \mathrm{~m}}$ rises more than $T_{\mathrm{c}}$ for the Eemian. However, Eemian late summer precipitation is significantly enhanced at the expense of winter precipitation: this causes $T_{\mathrm{c}}$ increase more than $T_{2 \mathrm{~m}}$.

\section{Conclusions}

Using output of the regional atmospheric climate model RACMO2, the impact of local and regional climate conditions on $T_{\mathrm{c}}$ is investigated for current, preindustrial and Eemian (125 kyr BP) climate in Greenland. In all cases, precipitation seasonality is an important factor for the local $T_{\mathrm{c}}$. For most of Greenland, most precipitation falls in the summer months, indicating that isotopic records are more influenced by summer precipitation.

Our model results show that the condensation temperature $\left(T_{\mathrm{c}}\right)$ does not clearly relate to near-surface, e.g. $T_{2 \mathrm{~m}}$ or free atmosphere, e.g. $T_{500 \mathrm{hPa}}$, temperatures. This is firstly due to the mean elevation at which precipitation is formed. Most precipitation originates from the lower troposphere, but is not influenced by the boundary layer processes that govern $T_{2 \mathrm{~m}}$.
$T_{\mathrm{c}}$ does not relate to $T_{500 \mathrm{hPa}}$ because of the spatial variation of the typical condensation elevation as a result of atmospheric temperature and surface topography. Moreover, precipitation seasonality causes $T_{\mathrm{c}}$ to reflect mostly summer conditions; $T_{\mathrm{c}}$ is thus higher than the average temperature of the atmospheric levels from which this precipitation originates.

Compared to the preindustrial climate, the ECHOG/RACMO2 realization of the Eemian climate has only limited annual warming (up to $1 \mathrm{~K}$ ) over the GrIS and the Northern Hemisphere. Nevertheless, the model output compares relatively well with paleoclimate records outside Greenland. Despite the limited surface warming, $T_{\mathrm{c}}$ over Northern Greenland was much higher during the Eemian than in preindustrial conditions. Enhanced precipitation seasonality compared to the preindustrial and current climate causes $T_{\mathrm{c}}$ to increase more than near-surface and free atmosphere temperature. As a result, the anomaly in $T_{\mathrm{c}}(-1$ to $3 \mathrm{~K})$ exceeds the anomalies in $T_{2 \mathrm{~m}}$ and $T_{500 \mathrm{hPa}}$ (both 0 to $1 \mathrm{~K}$ ). For comparison, if the present-day relation between cloud arrival temperature and $\delta^{18} \mathrm{O}$ for NAO variability would be valid for these anomalies, these changes in $T_{\mathrm{c}}$ relate to -1 to $+3 \%$ change in $\delta^{18} \mathrm{O}$.

The results of our study compare well with the estimated precipitation effect on Eemian $\delta^{18} \mathrm{O}$ as presented by Masson-Delmotte et al. (2011). The results shown here are based on climate realizations of one GCM/RCM combination which inhibits an assessment of the uncertainty range of these anomalies. However, the GCM/RCM combination of ECHO-G and RACMO2 provides a realistic climate realization; this study, therefore, shows that the impact of changing precipitation seasonality on $T_{\mathrm{c}}$ can not be excluded a priori.

In conclusion, the condensation temperature is an important factor for isotope physics, but many more processes play a role in the fractionation, for example, the temperature of the moisture source. It is, therefore, not straightforward to relate 
the observed sensitivity of $T_{\mathrm{c}}$ to precipitation seasonality to a sensitivity of isotopic properties, like $\delta^{18} \mathrm{O}$, to precipitation seasonality. This study, however, shows that Eemian isotopic proxies from ice cores are likely affected by changes in precipitation seasonality. The induced uncertainty due to possible changes in precipitation seasonality in Eemian temperature estimates based on ice core data is up to $2 \mathrm{~K}$. This uncertainty can only be reduced by explicitly modeling the Eemian climate and $\delta^{18} \mathrm{O}$ patterns with GCMs that included isotope physics. Once these models match Eemian ice core records as well as other proxies, the range of possible Eemian warming scenarios over the Greenland ice sheet will be reduced.

Acknowledgements. George Hoffman is thanked for valuable discussions. This work was sponsored by the Stichting Nationale Computerfaciliteiten (National Computing Facilities Foundation, $\mathrm{NCF}$ ) for the use of supercomputer facilities, with financial support from the Nederlandse Organisatie voor Wetenschappelijk Onderzoek (Netherlands Organization for Scientific Research, NWO).

Edited by: S. Bronnimann

\section{References}

Dansgaard, W.: Stable isotopes in precipitation, Tellus, 16, 436468, 1964.

EPICA community members: Eight glacial cycles from an Antarctic ice core, Nature, 429, 623-628, 2004.

Ettema, J., van den Broeke, M. R., van Meijgaard, E., van de Berg, W. J., Bamber, J. L., Box, J. E., and Bales, R. C.: Higher surface mass balance of the Greenland ice sheet revealed by highresolution climate modeling, Geophys. Res. Lett., 36, L12501, doi:10.1029/2009GL038110, 2009.

Ettema, J., van den Broeke, M. R., van Meijgaard, E., and van de Berg, W. J.: Climate of the Greenland ice sheet using a highresolution climate model - Part 2: Near-surface climate and energy balance, The Cryosphere, 4, 529-544, doi:10.5194/tc-4529-2010, 2010a.

Ettema, J., van den Broeke, M. R., van Meijgaard, E., van de Berg, W. J., Box, J. E., and Steffen, K.: Climate of the Greenland ice sheet using a high-resolution climate model - Part 1: Evaluation, The Cryosphere, 4, 511-527, doi:10.5194/tc-4-511-2010, $2010 \mathrm{~b}$.

Francis, D. R., Wolfe, A. P., Walker, I. R., and Miller, G. H.: Interglacial and Holocene temperature reconstructions based on midge remains in sediments of two lakes from Baffin Island, Nunavut, Arctic Canada, Palaeogeogr. Palaeocl., 236, 107-124, 2006.

Helsen, M. M., van de Wal, R. S. W., van den Broeke, M. R., Kerstel, E. R. T., Masson-Delmotte, V., Meijer, H. A. J., Reijmer, C. H., and Scheele, M. P.: Modelling the Isotopic Composition of Snow Using Backward trajectories: a Particular Precipitation Event in Dronning Maud Land, Antarctica, Ann. Glaciol., 39, 293-299, 2004.
Jansen, E. J., Overpeck, J., Briffa, K. R., Duplessy, J.-C., Joos, F., Masson-Delmotte, V., Olago, D., Otto-Bliesner, B., Peltier, W. R., Rahmstorf, S., Ramesh, R., Raynaud, D., Rind, D., Solomina, O., Villalba, R., and Zhang, D.: Climate Change 2007 - The Physical Science Basis, in: Palaeoclimate, Cambridge University Press, 2007.

Johnsen, S. J.: Stable isotopes profiles compared with temperature profiles in firn and with historical temperature records, in: Proceedings of Symposium on Isotopes and Impurities in Snow and Ice, vol. 118, International Association of Hydrological Sciences, Grenoble, 388-392, 1977.

Johnsen, S. J. and Vinther, B. M.: Greenland Stable Isotopes, in: Encyclopedia of Quarternary Science, Elsevier, 1250-1258, 2007.

Johnsen, S. J., Dansgaard, W., and White, J. W. C.: The origin of Arctic precipitation under present and glacial conditions, Tellus B, 41, 452-468, 1989.

Johnsen, S. J., Clausen, H. B., Dansgaard, W., Fuhrer, K., Gundestrup, N., Hammer, C. U., Iversen, P., Jouzel, J., Stauffer, B., and Steffensen, J. P.: Irregular glacial interstadials recorded in a new Greenland ice core, Nature, 359, 311-314, 1992.

Johnsen, S. J., Clausen, H. B., Dansgaard, W., Gundestrup, N. S., Hammer, C. U., Andersen, U., Anderson, K. K., Hvidberg, C. S., Dahl-Jensen, D., Steffensen, J. P., Shoji, H., Sveinbjörnsdóttir, A. E., White, J., Jouzel, J., and Fisher, D.: The $\delta^{18} \mathrm{O}$ record along the Greenland Ice Core Project deep ice core and the problem of possible Eemian climatic instability, J. Geophys. Res., 102, 26397-26410, 1997.

Johnsen, S. J., Clausen, H. B., Cuffey, K. M., Hoffmann, G., Schwandler, J., and Creyts, T.: Diffusion of stable isotopes in polar firn and ice: the isotope effect in firn diffusion, in: Physics of Ice Core Records, edited by: Hondoh, T., Hokkaido Univeristy Press, Sapporo, Japan, 121-140, 2000.

Jones, P. D., New, M., Parker, D. E., Martin, S., and Rigor, I. G.: Surface air temperature and its changes over the past 150 years, Rev. Geophys., 37, 173-199, 1999.

Jouzel, J., Alley, R. B., Cuffey, K. M., Dansgaard, W., Grootes, P., Hoffmann, G., Johnsen, S. J., Koster, R. D., Peel, D., Shuman, C. A., Stievenard, M., Stuiver, M., and White, J.: Validity of the temperature recontruction from water isotopes in ice cores, J. Geophys. Res., 102, 26471-26487, 1997.

Kaspar, F. and Cubasch, U.: The climate of past interglacials, in: Simulations of the Eemian interglacial and the subsequent glacial inception with a coupled ocean-atmosphere general circulation model, Elsevier, 2007.

Kaspar, F., Kühl, N., Cubasch, U., and Litt, T.: A model-data comparison of European temparatures in the Eemian interglacial, Geophys. Res. Lett., 32, L11703, doi:10.1029/2005GL022456, 2005.

Kaspar, F., Spangehl, T., and Cubasch, U.: Northern hemisphere winter storm tracks of the Eemian interglacial and the last glacial inception, Clim. Past, 3, 181-192, doi:10.5194/cp-3-181-2007, 2007.

Legutke, S. and Maier-Reimer, E.: Climatology of the ECHO-G Global Ocean - Sea Ice General Circulation Model, Technical Report 21, Deutsches Klimarechenzentrum, Hamburg, 1999.

Legutke, S. and Voss, R.: The Hamburg atmosphere-ocean coupled circulation model ECHO-G, Technical Report 18, Deutsches Klimarechenzentrum, Hamburg, 1999. 
Masson-Delmotte, V., Jouzel, J., Landais, A., Stievenard, M., Johnsen, S. J., White, J. W. C., Werner, M., Sveinbjornsdottir, A., and Fuhrer, K.: GRIP Deuterium Excess Reveals Rapid and Oribital-Scale Changes in Greenland Moisture Origin, Science, 309, 118-121, 2005.

Masson-Delmotte, V., Braconnot, P., Hoffmann, G., Jouzel, J., Kageyama, M., Landais, A., Lejeune, Q., Risi, C., Sime, L., Sjolte, J., Swingedouw, D., and Vinther, B.: Sensitivity of interglacial Greenland temperature and $\delta^{18} \mathrm{O}$ : ice core data, orbital and increased $\mathrm{CO}_{2}$ climate simulations, Clim. Past, 7, 10411059, doi:10.5194/cp-7-1041-2011, 2011.

McKay, N. P., Overpeck, J. T., and Otto-Bliesner, B. L.: The role of ocean thermal expansion in Last Interglacial sea level rise, Geophys. Res. Lett., 38, L14605, doi:10.1029/2011GL048280, 2011.

NEEM community members: Eemian interglacial reconstructed from a Greenland folded ice core, Nature, 493, 489-494, 2013.

NorthGRIP community members: High resolution climate record of the northern hemisphere reaching into last interglacial period, Nature, 431, 147-151, 2004.

Otto-Bliesner, B. L., Marshall, S. J., Overpeck, J. T., Miller, G. H., $\mathrm{Hu}, \mathrm{A}$., and CAPE Last Interglacial Project members: Simulating Arctic Climate Warmth and Icefield Retreat in the Last Interglaciation, Science, 311, 1751-1753, 2006.

Petit, J. R., Jouzel, J., Raynaud, D., Barnola, N. I., Basile, I., Bender, M., Chappallaz, J., Davis, M., Delaygue, G., Delmotte, M., Kotlyakov, V. M., Legrand, M., Lipenkov, V. Y., Lorius, C., Pépin, L., Ritz, C., Saltzman, E., and Stievenard, M.: Climate and atmospheric history of the past 420,000 years from the Vostok ice core, Antarctica, Nature, 399, 429-436, 1999.

Reeh, N.: Parameterization of melt rate and surface temperature on the Greenland ice sheet, Polarforschung, 59, 113-128, 1991.

Reijmer, C., van Meijgaard, E., and van den Broeke, M.: Numerical Studies with a Regional Atmospheric Climate Model Based on Changes in the Roughness Length for Momentum and Heat over Antarctica, Bound.-Lay. Meteorol., 111, 313-337, 2004.

Shuman, C. A., Bromwich, D. H., Kipfstuhl, J., and Schwager, M.: Multiyear accumulation and temperature history near the North Greenland Ice Core Project site, north central Greenland, J. Geophys. Res., 106, 33853-33866, 2001.

Sjolte, J., Hoffmann, G., Johnsen, S. J., Vinther, B. M., and MassonDelmotte, V.: Modeling the water isotopes in Greenland precipitation 1959-2001 with the meso-scale model REMO-iso, J. Geophys. Res., 116, D18105, doi:10.1029/2010JD015287, 2011.
Sodemann, H., Masson-Delmotte, V., Schwierz, C., Vinther, B. M., and Wernli, H.: Interannual variability of Greenland winter precipitation sources: 2. Effects of North Atlantic Oscillation variability on stable isotopes in precipitation, J. Geophys. Res., 113, D12111, doi:10.1029/2007JD009416, 2008.

Sturm, C., Zhang, Q., and Noone, D.: An introduction to stable water isotopes in climate models: benefits of forward proxy modelling for paleoclimatology, Clim. Past, 6, 115-129, doi:10.5194/cp-6-115-2010, 2010.

Turney, C. S. M. and Jones, R. T.: Does the Agulhas Current amplify global temperatures during super-interglacials, J. Quaternary Sci., 56, 839-843, 2010.

Undén, P., Rontu, L., Järvinen, H., Lynch, P., Calvo, J., Cats, G., Cuxart, J., Eerola, K., Fortelius, C., Garcia-Moya, J. A., Jones, C., Lenderlink, G., McDonald, A., McGrath, R., Navascues, B., Nielsen, N. W., Ødegaard, V., Rodriguez, E., Rummukainen, M., Rõõm, R., Sattler, K., Sass, B. H., Savijärvi, H., Wichers Schreur, B., Sigg, R., The, H., and Tijm, A. B. C.: The High Resolution Limited Area Model, Hirlam-5 scientific documentation, Swedish Meteorological and Hydrological Institute, Norrköping, Sweden, 2002.

Uppala, S. M., Kållberg, P. W., Simmons, A. J., Andrae, U., Bechtold, V. D. C., Fiorino, M., Gibson, J. K., Haseler, J., Hernandez, A., Kelly, G. A., Li, X., Onogi, K., Saarininen, S., Sokka, N., Allan, R. P., Andersson, E., Apre, K., Balmaseda, M. A., Beljaars, A. C. M., van de Berg, L., Bidlot, J., Bormann, N., Caires, S., Chevallier, F., and Dethof, A.: The ERA-40 re-analysis, Q. J. Roy. Meteorol. Soc., 131, 2961-3012, 2005.

van de Berg, W. J., van den Broeke, M. R., Ettema, J., van Meijgaard, E., and Kaspar, F.: Significant contribution of insolation to Eemian melting of the Greenland ice sheet, Nat. Geosci., 4, 679-683, 2011.

van den Broeke, M. R., Bamber, J., Ettema, J., Rignot, E., Schrama, E., van de Berg, W. J., van Meijgaard, E., Velicogna, I., and Wouters, B.: Partitioning Recent Greenland Mass Loss, Science, 326, 984-986, 2009.

van Meijgaard, E., van Ulft, L. H., van de Berg, W. J., Bosveld, F. C., van den Hurk, B. J. J. M., Lenderink, G., and Siebersma, A. P.: The KNMI regional atmospheric climate model RACMO version 2.1, Tech. Rep. 302, KNMI, De Bilt, the Netherlands, 2008.

Werner, M., Mikolajewicz, U., Heimann, M., and Hoffmann, G.: Borehole versus isotope temperatures on Greenland: Seasonality does matter, Geophys. Res. Lett., 27, 723-726, 2000.

White, P. W.: Part IV, Physical processes (CY23R4), European Centre For Medium-Range Weather Forecasts - ECMWF, Reading, UK, 2001. 